\title{
Adenovirus-Vectored COVID-19 Vaccine-Induced Immune Thrombosis of Carotid Artery
}

\section{A Case Report}

Uwe Walter, MD, FEAN, Mario Fuchs, Annette Grossmann, MD, Michael Walter, MD, Thomas Thiele, MD, Alexander Storch, MD, and Matthias Wittstock, MD

Neurology ${ }^{\circledR}$ 2021;97:716-719. doi:10.1212/WNL.0000000000012576

\section{Abstract}

\section{Objectives}

Venous thrombosis and thrombocytopenia after vaccination with the adenovirus-vectored COVID-19 vaccine ChAdOx1 nCov-19 (AstraZeneca) have been linked to serum antibodies against platelet factor 4 (PF4)-polyanion complexes. We here report vaccine-induced isolated carotid arterial thrombosis.

\section{Methods}

Imaging and laboratory findings, treatment decisions, and outcome of this case are presented.

\author{
Correspondence \\ Dr. Walter \\ uwe.walter@ \\ med.uni-rostock.de
}

\section{MORE ONLINE}

COVID-19 Resources

For the latest articles, invited commentaries, and blogs from physicians around the world

NPub.org/COVID19

\section{Video}

\section{Results}

Eight days after having received the first dose of ChAdOx1 nCov-19 vaccine, a 31-year-old man was admitted to our stroke unit with acute headache, aphasia, and hemiparesis. D-dimers were slightly elevated, but platelet count and fibrinogen level were normal. MRI-confirmed mainstem occlusion of middle cerebral artery resolved within 1 hour after the start of IV thrombolysis. A wall-adherent, nonoccluding thrombus in the ipsilateral carotid bulb was identified as the source of embolism. Cardiac or paradoxical (venous) embolism was excluded. Screening for the presence of heparin-induced thrombocytopenia-related antibodies was positive, and highly elevated serum IgG antibodies against PF4-polyanion complexes were subsequently proven. Treatment with aspirin and subcutaneous danaparoid, followed by phenprocoumon, led to thrombus shrinkage and dissolution within 19 days and favorable clinical outcome.

\section{Discussion}

Vaccine history is important in patients not only with venous but also with arterial thromboembolic events. Vaccine-induced immune thrombosis of brain-supplying arteries may well be handled.

From the Department of Neurology (U.W., M.F., A.S., M. Wittstock), Rostock University Medical Center, Rostock, Germany; Institute of Diagnostic and Interventional Radiology, Pediatric Radiology and Neuroradiology (A.G.), Rostock University Medical Center, Rostock, Germany; Institute of Clinical Chemistry and Laboratory Medicine (M. Walter), Rostock University Medical Center, Rostock, Germany; and Institute of Immunology and Transfusion Medicine (T.T.), Greifswald University Medical Center, Greifswald, Germany.

Go to Neurology.org/N for full disclosures. Funding information and disclosures deemed relevant by the authors, if any, are provided at the end of the article. 
Figure 1 Imaging of Brain and Intracranial Arteries
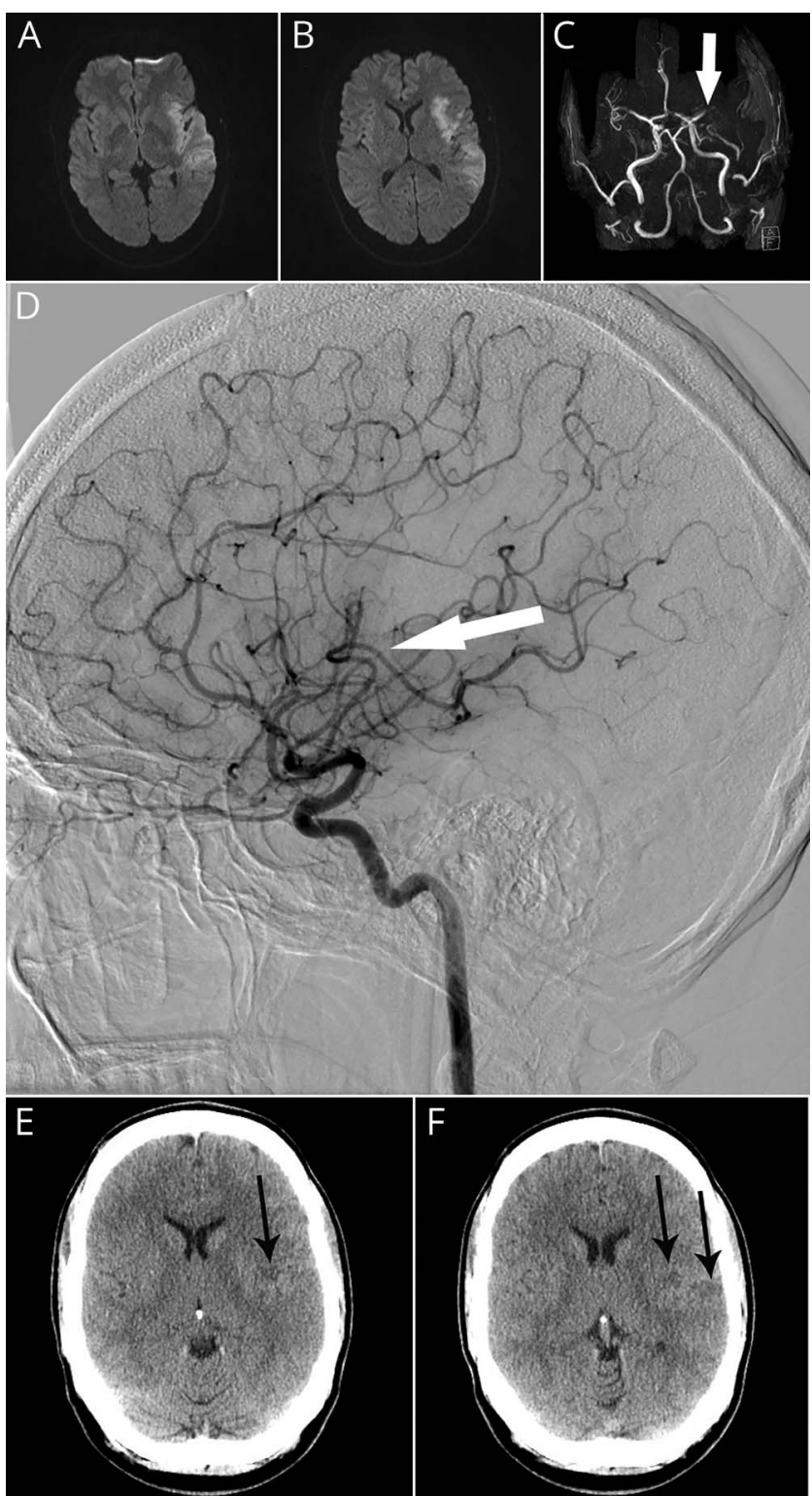

Multimodal imaging findings of brain and intracranial arteries of the patient with acute ischemic stroke on postvaccination day 8. (A, B) Diffusionweighted MRI showing acute ischemia in the territory of left middle cerebral artery (MCA). (C) Time-of-flight MR angiography showing distal mainstem occlusion of left MCA (arrow). (D) Digital subtraction angiogram 50 minutes after the start of IV thrombolysis therapy confirmed reperfusion of the M1 and $M 2$ segments of left MCA, with only a small temporal M3 branch remaining occluded (arrow). (E, F) CT scan performed 24 hours after thrombolysis therapy showing small infarctions in the left insular and temporal cortex (arrows).

To fight the COVID-19 pandemic, the European Medicines Agency approved 4 vaccines until March 2021. Of these, ChAdOxl nCoV-19 (AstraZeneca) is a replication-defective, chimpanzee adenovirus-vectored vaccine containing the fulllength severe acute respiratory syndrome coronavirus type 2 (SARS-CoV-2) spike glycoprotein gene. ${ }^{1}$ In recently reported 23 patients naïve to heparin with ChAdOxl nCov-19 vaccine-induced thrombosis and thrombocytopenia (VITT), highly elevated serum IgG antibodies to platelet factor 4 (PF4)- polyanion complexes were found. ${ }^{2-4}$ VITT typically manifests with, often cerebral, venous thromboses, and also a few arterial thromboses were noted. ${ }^{2-5}$ In this study, we describe a case with isolated arterial thrombosis in the presence of strong reacting platelet-activating antibodies directed against PF4.

\section{Methods}

The local ethics committee approved this study (identifier: A2021-0089). The patient provided written informed consent.

\section{Results}

\section{Clinical Presentation}

A 31-year-old childcare worker was admitted to our stroke unit with acute headache, aphasia, and incomplete right-sided hemiparesis. He had received his first dose of ChAdOx1 nCoV-19 vaccine 8 days before and suffered minor symptoms (fatigue, myalgia, and mild headache) over a few days but then remained asymptomatic until day 8 , when he experienced sudden-onset severe headache. The headache persisted despite taking cumulatively $2 \mathrm{~g}$ of paracetamol. He was feeling weary and spent most of the day sleeping. When waking him up, his partner noticed hemiplegia and speech arrest and called emergency.

He had no preexisting medical condition and did not regularly take any medication. The only cardiovascular risk factor was cigarette smoking (10/d) since 12 years. His grandfather had had a stroke in high age; there were no further cardiovascular events in family history.

\section{Diagnostic Findings}

An MRI examination on admission revealed acute ischemia of left middle cerebral artery (MCA) territory due to distal MCA mainstem occlusion (Figure 1). IV thrombolysis with alteplase was started, and urgent thrombectomy was planned. On catheter angiography, however, the MCA-M1 and MCA-M2 segments were reperfused 50 minutes after the start of alteplase; a wall-adherent carotid thrombus was noted, but no arterial dissection. Next-day CT scan of the brain showed 2 small areas of brain infarction. CT angiography and ultrasonography confirmed a parietal solid thrombus in the left carotid bulb (Figure 2), with a mobile tail at its proximal end (Video 1). Transesophageal echocardiography and transcranial Doppler testing with agitated saline excluded an aortic, cardiac, or paradoxical (venous) source of embolism. Thus, the carotid thrombus was regarded being the source of embolism into the MCA.

Initial blood tests showed slightly increased D-dimers, leukocyte counts, and C-reactive protein (Table). Platelet count and fibrinogen level were normal, as well as standard laboratory workup, including serum lipids, homocysteine, and lipoprotein (a), screening for thrombophilia (antithrombin III, factor V, factor VIII, protein $\mathrm{C}$, activated protein $\mathrm{C}$ resistance, antiphospholipid antibodies, and search for prothrombin 

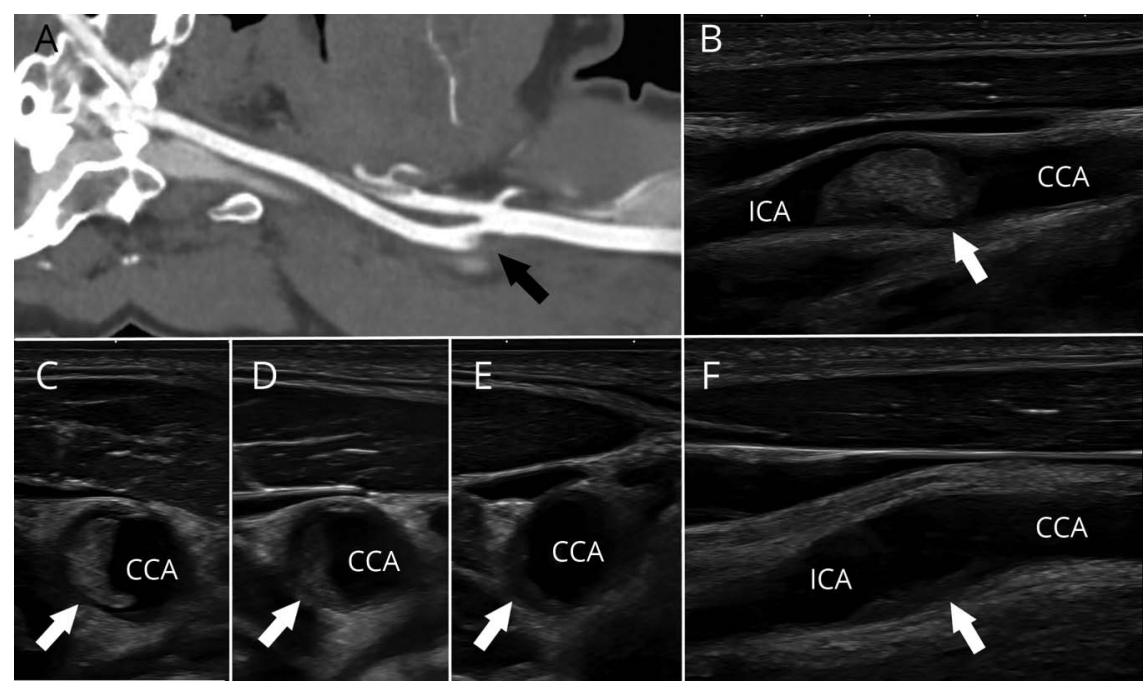

Multimodal imaging findings of left common carotid artery (CCA) and internal carotid artery (ICA) on postvaccination days 11,16 , and 23 . (A) CT angiogram (day 11) showing a parietal thrombus in the CCA bulb, extending into the offspring of ICA, causing a lumen stenosis of $<50 \%$ (arrow). (B) Coronal sonogram (day 11) of this wall-adherent 190- $\mathrm{mm}^{3}$ thrombus (arrow). (C) Axial sonogram (day 11) of this mostly solid, nonoccluding thrombus with a slightly mobile tail at its proximal end (arrow; see also the Video 1). (D) Axial sonogram (day 16) at the same level as shown in (C), demonstrating beginning shrinkage $\left(140 \mathrm{~mm}^{3}\right)$ of the thrombus (arrow). (E) Axial sonogram (day 23) at the same level as shown in (C), demonstrating marked shrinkage $\left(50 \mathrm{~mm}^{3}\right)$ of the thrombus (arrow). (F) Sagittal sonogram (day 23) of the residual thrombus (arrow).

mutation g.20210 G > A), and tests for antinuclear antibodies and antineutrophil cytoplasmic antibodies. Because the thrombosis occurred within the typical time window for VITT, ${ }^{2}$ we screened for heparin-induced thrombocytopenia-related antibodies despite normal platelet count, with a positive test result. Subsequent workup proved highly elevated serum IgG antibodies against PF4-polyanion complexes. These antibodies activated platelets in the presence of PF4 in a washed platelet activation assay. $^{2}$

\section{Treatment and Outcome}

IV thrombolysis entailed dramatic neurologic recovery within 1 hour. Symptoms persisting on days 9-28 were slight phonemic paraphasia and difficulties in complex cognitive tasks.

Table Laboratory and Sonographic Findings 8-28 d After Vaccination (Stroke Onset on Day 8)

\begin{tabular}{|c|c|c|c|c|c|c|c|c|}
\hline \multirow[b]{2}{*}{ Parameter } & \multirow[b]{2}{*}{ Reference } & \multicolumn{7}{|c|}{ Findings on postvaccination day no. } \\
\hline & & 8 & 9 & 10 & 11 & 18 & 23 & 28 \\
\hline \multicolumn{9}{|l|}{ Laboratory findings } \\
\hline Platelet count, $10^{9} / \mathrm{L}$ & $150-450$ & 217 & 159 & 152 & 165 & 196 & 208 & 201 \\
\hline Leukocyte count, $10^{9} / \mathrm{L}$ & $4-9$ & 10.5 & 9.72 & 7.54 & 8.46 & 7.19 & 6.49 & 7.17 \\
\hline C-reactive protein, mg/L & $<5.0$ & 13.0 & & 12.5 & 22.8 & & 3.0 & \\
\hline Prothrombin time, INR & $0.80-1.25$ & 0.98 & & 1.05 & 1.03 & $2.42^{a}$ & $2.57^{a}$ & $2.01^{a}$ \\
\hline Activated partial thromboplastin time, s & $27-37$ & 27.5 & & 30.1 & 29.4 & & $40.6^{a}$ & $40.9^{a}$ \\
\hline Fibrinogen, g/L & $1.8-3.5$ & 2.7 & & 2.5 & & & 2.3 & \\
\hline D-dimers, mg/L & $<0.5$ & 1.1 & & & & & 0.48 & 0.34 \\
\hline Heparin/PF4 IgG-specific ELISA & Neg & & Pos & & & & Pos & \\
\hline Heparin-induced platelet activation test & Neg & & Neg & & & & Neg & \\
\hline Vaccine-induced platelet activation test & Neg & & Pos & & & & ND & \\
\hline SARS-CoV-2 RT-PCR test & Neg & Neg & Neg & & & & & \\
\hline \multicolumn{9}{|l|}{ Sonographic findings } \\
\hline Carotid thrombus volume, $\mathrm{mm}^{3}$ & 0 & & 190 & & 190 & 140 & 50 & 0 \\
\hline
\end{tabular}

Abbreviations: INR = international normalized ratio; Neg = negative; PF4 = platelet factor 4; Pos = positive; RT-PCR = reverse transcriptase-PCR Abnormal findings in bold.

a Values increased on oral anticoagulant therapy with vitamin $\mathrm{K}$ antagonist (phenprocoumon). 
Combined anticoagulation with aspirin $100 \mathrm{mg} / \mathrm{d}$ and subcutaneous danaparoid $2 \times 750 \mathrm{mg} / \mathrm{d}$ on days 9-13, followed by phenprocoumon (target international normalized ratio 2-3), ${ }^{6}$ led to marked thrombus shrinkage (Figure 2, Video 1) and complete dissolution on day 28 .

\section{Discussion}

We report on a young patient with ischemic stroke in a typical time window for VITT, ${ }^{2-5}$ without definite thrombocytopenia. For immunogenic thrombocytopenia, a platelet count fall of $>50 \%$ in 48 hours is also relevant, which may have occurred within normal platelet counts. He had isolated carotid arterial thrombosis with secondary embolism into the MCA, along with highly elevated antibodies against PF4-polyanion complexes, but normal platelet counts. Therefore, standard IV thrombolysis with alteplase and subsequent aspirin, followed by oral vitamin $\mathrm{K}$ antagonist anticoagulation, was initiated and led to favorable outcome. Vitamin $\mathrm{K}$ antagonist anticoagulation in early stage of VITT occurring with thrombocytopenia and disseminated intravascular coagulation is not recommended because of the rapid decline of protein $\mathrm{C}$, which could potentially aggravate thrombosis. However, we considered the use as safe because no thrombocytopenia and no signs of disseminated intravascular coagulation were present in our patient. To avoid heparin administration, danaparoid was given for prophylaxis of deep vein thrombosis. Treatment with intravenous immunoglobulins, recommended particularly for vaccinationinduced cerebral venous sinus thrombosis to interrupt $\mathrm{Fc} \gamma$ receptor-mediated platelet activation, ${ }^{2,7}$ was omitted here because of normal platelet counts.

We conclude that any unusual thrombosis 4-20 days after vector-based vaccination against COVID-19 should prompt investigation of VITT antibodies.

\section{Acknowledgment}

The authors wish to thank the patient for agreeing with this case report and Kerstin Baier, Information Technology and Media Center at Rostock University, for technical realization of the accompanying video.

\section{Study Funding}

The authors report no targeted funding.

\section{Disclosure}

The authors report no disclosures relevant to the manuscript. Go to Neurology.org/N for full disclosures.

\section{Publication History}

Received by Neurology April 22, 2021. Accepted in final form July 19, 2021.

\section{Appendix Authors}

\begin{tabular}{lll}
\hline Name & Location & Contribution \\
\hline $\begin{array}{lll}\text { Uwe Walter, } \\
\text { MD, FEAN }\end{array}$ & $\begin{array}{ll}\text { Department of Neurology, } \\
\text { Center, Rostock, Germany }\end{array}$ & $\begin{array}{l}\text { Drafting/revision of the } \\
\text { article for content, including } \\
\text { medical writing for content; } \\
\end{array}$ \\
& $\begin{array}{l}\text { major role in the acquisition } \\
\text { of data; study concept or } \\
\text { design; and analysis or } \\
\text { interpretation of data }\end{array}$ \\
\end{tabular}

\begin{tabular}{ll}
\hline Mario Fuchs & Department of Neurology, \\
& Rostock University Medical \\
& Center, Rostock, Germany
\end{tabular}

Drafting/revision of the article for content, including medical writing for content, and analysis or

interpretation of data

\begin{tabular}{|c|c|c|}
\hline $\begin{array}{l}\text { Annette } \\
\text { Grossmann, } \\
\text { MD }\end{array}$ & $\begin{array}{l}\text { Institute of Diagnostic and } \\
\text { Interventional Radiology, } \\
\text { Pediatric Radiology and } \\
\text { Neuroradiology, Rostock } \\
\text { University Medical Center, } \\
\text { Rostock, Germany }\end{array}$ & $\begin{array}{l}\text { Drafting/revision of the } \\
\text { article for content, including } \\
\text { medical writing for content; } \\
\text { major role in the acquisition } \\
\text { of data; and analysis or } \\
\text { interpretation of data }\end{array}$ \\
\hline $\begin{array}{l}\text { Michael } \\
\text { Walter, MD }\end{array}$ & $\begin{array}{l}\text { Institute of Clinical Chemistry } \\
\text { and Laboratory Medicine, } \\
\text { Rostock University Medical } \\
\text { Center, Rostock, Germany }\end{array}$ & $\begin{array}{l}\text { Drafting/revision of the } \\
\text { article for content, including } \\
\text { medical writing for content; } \\
\text { major role in the acquisition } \\
\text { of data; and analysis or } \\
\text { interpretation of data }\end{array}$ \\
\hline $\begin{array}{l}\text { Thomas } \\
\text { Thiele, MD }\end{array}$ & $\begin{array}{l}\text { Institute of Immunology and } \\
\text { Transfusion Medicine, } \\
\text { Greifswald University } \\
\text { Medical Center, Greifswald, } \\
\text { Germany }\end{array}$ & $\begin{array}{l}\text { Drafting/revision of the } \\
\text { article for content, including } \\
\text { medical writing for content; } \\
\text { major role in the acquisition } \\
\text { of data; and analysis or } \\
\text { interpretation of data }\end{array}$ \\
\hline $\begin{array}{l}\text { Alexander } \\
\text { Storch, MD }\end{array}$ & $\begin{array}{l}\text { Department of Neurology, } \\
\text { Rostock University Medical } \\
\text { Center, Rostock, Germany }\end{array}$ & $\begin{array}{l}\text { Drafting/revision of the } \\
\text { article for content, including } \\
\text { medical writing for content, } \\
\text { and analysis or } \\
\text { interpretation of data }\end{array}$ \\
\hline $\begin{array}{l}\text { Matthias } \\
\text { Wittstock, } \\
\text { MD }\end{array}$ & $\begin{array}{l}\text { Department of Neurology, } \\
\text { Rostock University Medical } \\
\text { Center, Rostock, Germany }\end{array}$ & $\begin{array}{l}\text { Drafting/revision of the } \\
\text { article for content, including } \\
\text { medical writing for content; } \\
\text { major role in the acquisition } \\
\text { of data; and analysis or } \\
\text { interpretation of data }\end{array}$ \\
\hline
\end{tabular}

\section{References}

1. Voysey M, Clemens SAC, Madhi SA, et al. Safety and efficacy of the ChAdOx1 $\mathrm{nCoV}-19$ vaccine (AZD1222) against SARS-CoV-2: an interim analysis of four randomised controlled trials in Brazil, South Africa, and the UK. Lancet. 2021; 397(10269):99-111.

2. Greinacher A, Thiele T, Warkentin TE, Weisser K, Kyrle PA, Eichinger S. Thrombotic thrombocytopenia after ChAdOx1 nCov-19 vaccination. N Engl J Med. 2021;384(22): 2092-2101.

3. Schultz NH, Sørvoll IH, Michelsen AE, et al. Thrombosis and thrombocytopenia after ChAdOxl nCoV-19 vaccination. N Engl J Med. 2021;384(22):2124-2130.

4. Scully M, Singh D, Lown R, et al. Pathologic antibodies to platelet factor 4 after ChAdOx1 nCoV-19 vaccination. N Engl J Med. 2021;384(23):2202-2211.

5. Mehta PR, Mangion SA, Benger M, et al. Cerebral venous sinus thrombosis and thrombocytopenia after COVID-19 vaccination-a report of two UK cases. Brain Behav Immun. 2021;95:514-517.

6. Cuker A. Management of the multiple phases of heparin-induced thrombocytopenia. Thromb Haemost. 2016;116(5):835-842.

7. Oldenburg J, Klamroth R, Langer F, et al. Diagnosis and Management of VaccineRelated Thrombosis following AstraZeneca COVID-19 Vaccination: Guidance Statement from the GTH. Hamostaseologie. 2021;41(3):184-189. 


\section{Neurology}

\section{Adenovirus-Vectored COVID-19 Vaccine-Induced Immune Thrombosis of Carotid Artery: A Case Report}

Uwe Walter, Mario Fuchs, Annette Grossmann, et al. Neurology 2021;97;716-719 Published Online before print July 26, 2021

DOI 10.1212/WNL.0000000000012576

This information is current as of July 26, 2021

\section{Updated Information \& Services}

References

Citations

Subspecialty Collections

Permissions \& Licensing

Reprints including high resolution figures, can be found at: http://n.neurology.org/content/97/15/716.full

This article cites 7 articles, 0 of which you can access for free at: http://n.neurology.org/content/97/15/716.full\#ref-list-1

This article has been cited by 1 HighWire-hosted articles: http://n.neurology.org/content/97/15/716.full\#\#otherarticles

This article, along with others on similar topics, appears in the following collection(s):

\section{COVID-19}

http://n.neurology.org/cgi/collection/covid_19

Stroke in young adults

http://n.neurology.org/cgi/collection/stroke_in_young_adults Ultrasound

http://n.neurology.org/cgi/collection/ultrasound

Information about reproducing this article in parts (figures,tables) or in its entirety can be found online at:

http://www.neurology.org/about/about_the_journal\#permissions

Information about ordering reprints can be found online:

http://n.neurology.org/subscribers/advertise

Neurology ${ }^{\circledR}$ is the official journal of the American Academy of Neurology. Published continuously since 1951, it is now a weekly with 48 issues per year. Copyright () 2021 American Academy of Neurology. All rights reserved. Print ISSN: 0028-3878. Online ISSN: 1526-632X.

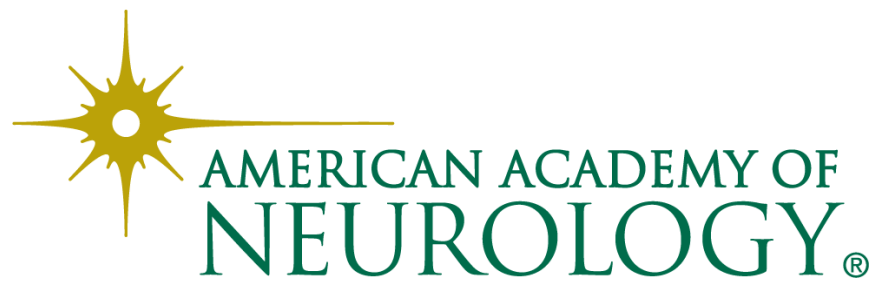

